\title{
Effect of the fungus Paecilomyces lilacinus on the larval population and root knot formation of Meloidogyne incognita in tomato ${ }^{1}$
}

\author{
Jessé Román and Arcángel Rodríguez-Marcano ${ }^{2}$
}

\begin{abstract}
Two experiments were conducted in the greenhouse to determine the effect of the fungus Paecilomyces lilacinus in controlling the larvae and root knot or root gall formation of Meloidogyne incognita in tomato cultivar Floradel. The plants were inoculated with the fungus alone, the nematode alone or both simultaneously at different time intervals and combinations. Observations made 60 days after the inoculations showed that the fungus controlled the nematodes and reduced root knot formation. In the first experiment, significantly fewer larvae were found in roots and soil of plants inoculated with the fungus 3 days previous to nematode inoculation. A higher root knot index in plants inoculated with nematodes alone; with fungus and nematodes simultaneously; and with the fungus alone 3 days after nematode inoculation was also obtained. In the second experiment, a tendency for a reduced number of nematodes in soil and roots and low gall indices was observed as the time of inoculation of the fungus before the nematode inoculation was increased. Plants inoculated with the fungus 4 and 6 days before nematode inoculation had significantly lower gall indices than the other plants inoculated with the nematode, the fungus, or both.
\end{abstract}

\section{INTRODUCTION}

The root knot nematode, Meloidogyne incognita (Kofoid and White) Chitwood, is an important pest affecting tomato production worldwide. Chemical treatment of the soil has been an extensively used practice for many years. However, scientists are every day more concerned about the adverse effects that this practice may have in man and his environment. Therefore, more attention is being given to the use of other control practices which may reduce the amount of chemicals used in agriculture. Thus, although biological control has been known and used for many years, it was during the seventies that its potential in controlling pests and diseases has been stressed.

One of the biological control practices attempted is the study of fungi that attack the eggs of Meloidogyne Goeldi. Sterling and Mankau described a new fungal parasite of Meloidogyne eggs (11). Jatala et al. reported on the use of Paecilomyces lilacinus (Thom) Samson in controlling root knot of potatoes in Peru $(8,9,10)$. Dunn et al. published on the colonization of $M$. incognita eggs by $P$. lilacinus as seen through the scanning microscope (5). Candanedo-Lay et al. reported on the control of root knot and potato cyst nematodes by $P$. lilacinus $(2,3)$. Godoy et

\footnotetext{
${ }^{1}$ Manuscript submitted to Editorial Board June 28, 1984.

${ }^{2}$ Nematologist and Associate Phytopathologist, Agricultural Experiment Station, University of Puerto Rico, Mayagüez Campus, respectively. Photos by Mr. D. Oramas.
} 
al. succeeded in parasitizing eggs of Heterodera glycines Ichinohe and $M$. arenaria (Neal) Chitwood with Verticillium lamellicola (F.E.V. Smith) W. Gams and V. leptobactrum E. Gams under in vitro conditions (7). Godoy et al. found $P$. lilacinus to be the fungus most frequently encountered parasitizing eggs of $M$. arenaria in an Alabama soil (6). In view of the above findings, studies were conducted in the greenhouse to determine the efficacy of the fungus $P$. lilacinus in controlling the larval population of $M$. incognita and the nodulations formed in tomato roots.

\section{MATERIALS AND METHODS}

Two experiments were conducted in the greenhouse. In the first experiment, $12-\mathrm{cm}$ high tomato plants, cv. Floradel, planted in $20-\mathrm{cm}$ diameter clay pots containing $2,000 \mathrm{~cm}^{3}$ of steam sterilized soil, were inoculated with eggs of $M$. incognita and spores of $P$. lilacinus in various combinations (table 1). Nematode eggs were obtained from infected

TABLE 1.-Effect of the fungus Paecilomyces lilacinus in the larval population of

Meloidogyne incognita and root knot formation in tomato cv. Floradel (Exp. No. 1)

\begin{tabular}{|c|c|c|c|}
\hline \multirow{3}{*}{ Treatment } & \multicolumn{3}{|c|}{ Average values } \\
\hline & \multicolumn{2}{|c|}{ No. of larvae } & \multirow{2}{*}{$\frac{\text { Root-knot index }}{(0-5)}$} \\
\hline & Soil & Roots & \\
\hline Nematode $(\mathrm{N})$ & $2,188 \mathrm{a}$ & 7,524 a & $4.9 \mathrm{a}$ \\
\hline Fungus $(\mathrm{F})$ & $0 \mathrm{~b}$ & $0 \mathrm{c}$ & $0 \mathrm{~d}$ \\
\hline $\mathrm{N}+\mathrm{F}$ simultaneously & $1,980 \mathrm{a}$ & $2,569 \mathrm{bc}$ & $4.2 \mathrm{~b}$ \\
\hline F 3 days before $N$ & $0 \mathrm{~b}$ & $327 \mathrm{c}$ & $3.0 \mathrm{c}$ \\
\hline F 3 days after $N$ & $2,366 \mathrm{a}$ & $3,826 \mathrm{~b}$ & $5.0 \mathrm{a}$ \\
\hline Check & $0 \mathrm{~b}$ & $0 \mathrm{c}$ & $0 \mathrm{~d}$ \\
\hline
\end{tabular}

tomato plants grown in steam sterilized soil, following the method of Taylor and Sasser (12). Twenty-five thousand eggs were inoculated per pot. A pure culture of $P$. lilacinus, obtained from Peru, S.A., was cultured on petri plates containing $20 \mathrm{~cm}^{3}$ of potato dextrose agar. Plates were incubated at $28^{\circ} \mathrm{C}$ for 9 to 10 days. After the incubation period, a spore suspension was prepared by pouring $15 \mathrm{~cm}^{3}$ of sterile water to each plate and gently scraping the agar surface with a glass microslide to separate the spores from the medium. The suspension was then filtered through a 44- $\mu$ mesh screen to remove pieces of agar and fungus mycellium. The filtered spore suspension was adjusted to $2.4 \times 10^{6}$ spores per $\mathrm{cm}^{3}$ of water with a hemacytometer counting chamber. One-hundred-fifty $\mathrm{cm}^{3}$ of the spore suspension was added to each pot. Treatments were replicated five times, arranged in a random block design and placed on a bench in the greenhouse. Sixty days after inoculation the plants were uprooted. A root-knot index, following the method of Taylor and Sasser 
(12), was given to each root system. The Christie and Perry method for extracting nematodes (4) was used to determine the nematodes present in $250 \mathrm{~cm}^{3}$ of soil. The whole root system of each plant was comminuted for $15 \mathrm{~s}$, and nematodes were extracted the same way as for the soil samples. Nematodes obtained were counted under a stereomicroscope and numbers recorded.

With the purpose of determining the optimum inoculation time for the fungus, a second experiment was conducted. This was similar to the first experiment except for the following: plants were planted in 5 gal plastic containers and inoculated with 409,180 eggs of Meloidogyne and $150 \mathrm{~cm}^{3}$ of a $P$. lilacinus suspension each containing $5.12 \times 10^{6}$ spores per $\mathrm{cm}^{3}$ of water. Ten treatments (table 2 ) were replicated four times and arranged in a balanced incomplete block design. Data obtained from both experiments were submitted to analysis of variance.

TABLE 2.-Effect of the fungus $\mathrm{P}$. lilacinus in the larval population of $\mathrm{M}$. incognita and root knot formation in tomato cv. Floradel (Exp. No. 2)

\begin{tabular}{lcccc}
\hline \multirow{2}{*}{ Treatment } & \multicolumn{3}{c}{ Average values } \\
\cline { 2 - 3 } & \multicolumn{2}{c}{ No. of larvae } & & Root-knot Index \\
\cline { 2 - 3 } & Soil & Roots & $(0-5)$ \\
Nematode $(\mathrm{N})$ & $1,974 \mathrm{a}$ & $8,069 \mathrm{abc}$ & $5.0 \mathrm{ab}$ \\
Fungus $(\mathrm{F})$ & $0 \mathrm{~b}$ & $0 \mathrm{cde}$ & $0 \mathrm{e}$ \\
$\mathrm{N}+\mathrm{F}$ simultaneously & $1,798 \mathrm{a}$ & $4,204 \mathrm{abcd}$ & $5.0 \mathrm{ab}$ \\
F 2 days before N & $841 \mathrm{ab}$ & $10,135 \mathrm{a}$ & $4.6 \mathrm{~b}$ \\
F 4 days before N & $319 \mathrm{~b}$ & $3,874 \mathrm{bcde}$ & $3.5 \mathrm{c}$ \\
F 6 days before N & $93 \mathrm{~b}$ & $1,490 \mathrm{de}$ & $2.9 \mathrm{~d}$ \\
F 2 days after N & $796 \mathrm{ab}$ & $4,535 \mathrm{abcd}$ & $4.9 \mathrm{ab}$ \\
F 4 days after N & $962 \mathrm{ab}$ & $9,096 \mathrm{ab}$ & $5.0 \mathrm{ab}$ \\
F 6 days after N & $1,869 \mathrm{a}$ & $3,341 \mathrm{cde}$ & $5.0 \mathrm{ab}$ \\
Check & $0 \mathrm{~b}$ & $0 \mathrm{e}$ & $0 \mathrm{e}$ \\
\hline
\end{tabular}

\section{RESULTS AND DISCUSSION}

Table 1 presents the results of the first experiment. No larvae were recovered from the soil of plants inoculated with the fungus alone, the noninoculated plants, or from plants inoculated with the fungus 3 days before the nematode inoculation. Significantly more soil larvae were found in plants inoculated with the nematode alone, with the nematode and fungus simultaneously, and with the fungus alone 3 days after the nematode inoculation. The highest number of larvae was found in the latter treatment. The number of nematodes recovered from the roots followed a similar pattern to that of nematodes recovered from soil. No nematodes were recovered from roots of plants treated with the fungus alone nor from those not inoculated. A significantly higher number of 
larvae was obtained from the roots of plants inoculated with the nematode alone and from those where the fungus was added 3 days after the nematode than from the roots of plants to which the fungus was added 3 days before the nematode. The highest number of larvae $(7,524)$ was recovered from the roots of plants inoculated with the nematode alone. This number was significantly different from those of all the other treatments.

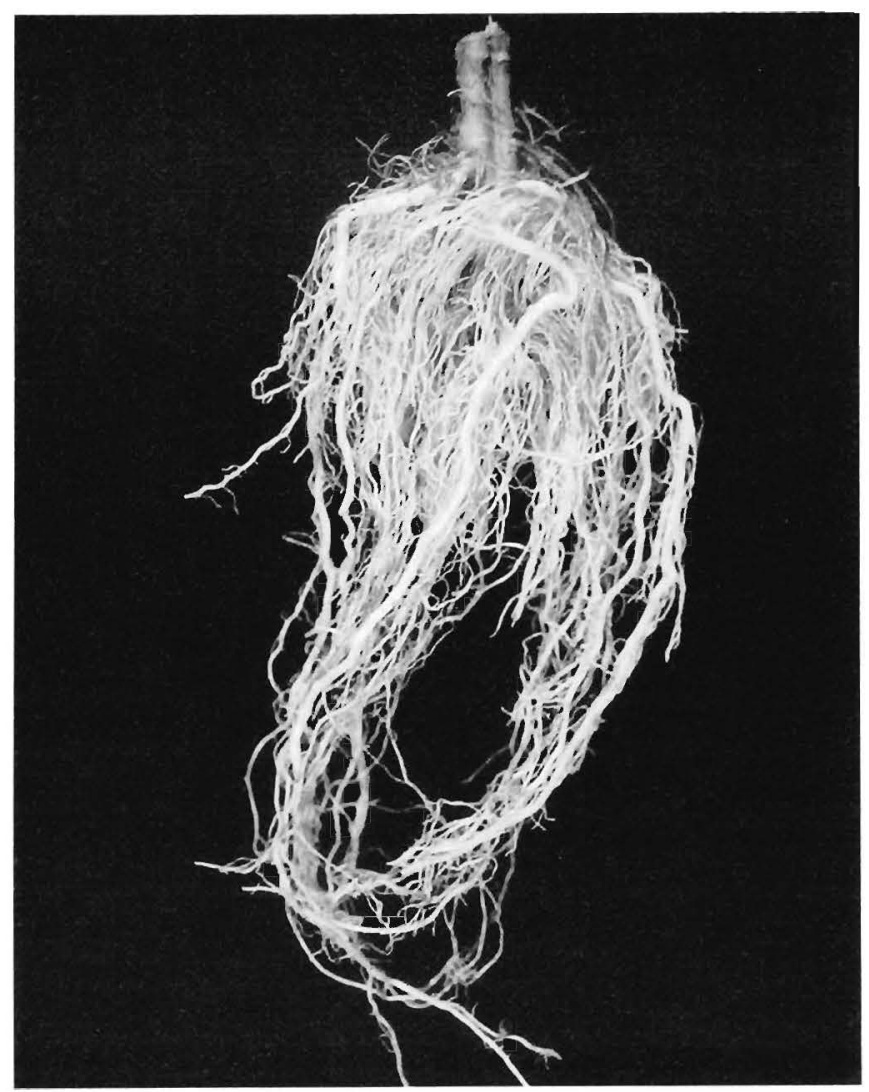

FIG. 1.-Roots of a plant inoculated with the fungus alone. No root galls are observed.

Regarding the root knot index, no galls were found in the noninoculated plants nor in those inoculated with the fungus alone. These two treatments were statistically similar to each other but different from all other treatments. The lowest root-knot index (3.0) was found in the roots of plants with the fungus added 3 days before the nematode. This value was significantly different from those in all other treatments. Highest root knot indices were found in roots of plants inoculated with the nematode 
alone (4.9), and in those inoculated with the fungus 3 days after the nematode (5.0). These values were statistically similar to each other but different from those of the other treatments.

Table 2 shows data obtained from the second experiment. No larvae were found in the soil of plants inoculated with the fungus alone or in the noninoculated controls. Significantly higher numbers of larvae were

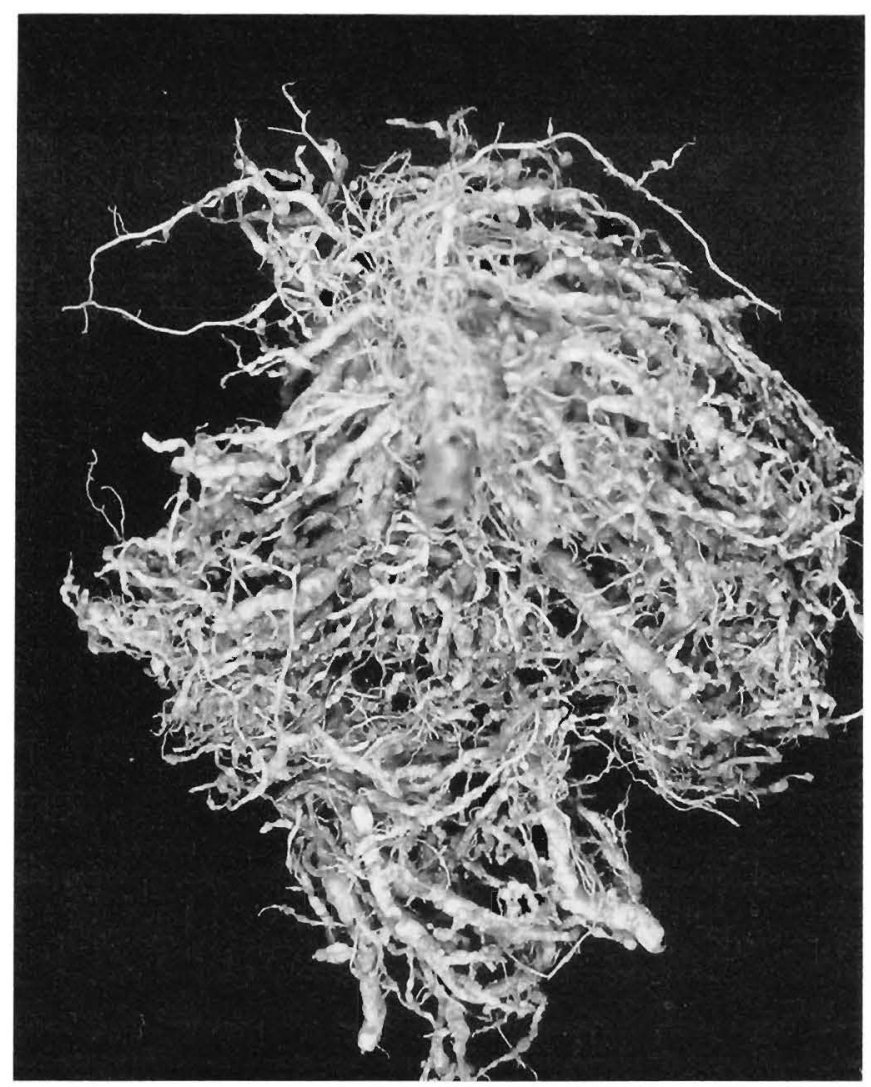

FIG. 2.-Roots of a plant inoculated with the nematode alone. Notice high incidence of root galls.

found in soil from plants inoculated with the nematode alone, with the nematode and fungus simultaneously and with the fungus alone added 6 days after the nematode, than those obtained from plants with the fungus added 4 and 6 days before the nematode. Similarly, no larvae were found in the roots of plants inoculated with the fungus alone nor in the noninoculated controls. The number of larvae from roots of plants with 
fungus added 2 days before the nematode and 4 days after the nematode, respectively, was significantly higher than that obtained from treatments with the fungus added 6 days before and after the nematode, separately.

With respect to the root knot indices, no galling was found in the roots of plants inoculated with the fungus alone (fig. 1) nor in those from noninoculated controls. Higher root knot indices (5.0) were obtained from roots of plants inoculated with the nematode alone (fig. 2); with the nematode and fungus added simultaneously (fig. 3 ) and with the fungus added 4 and 6 days after the nematode (fig. 4). Significantly lower gall

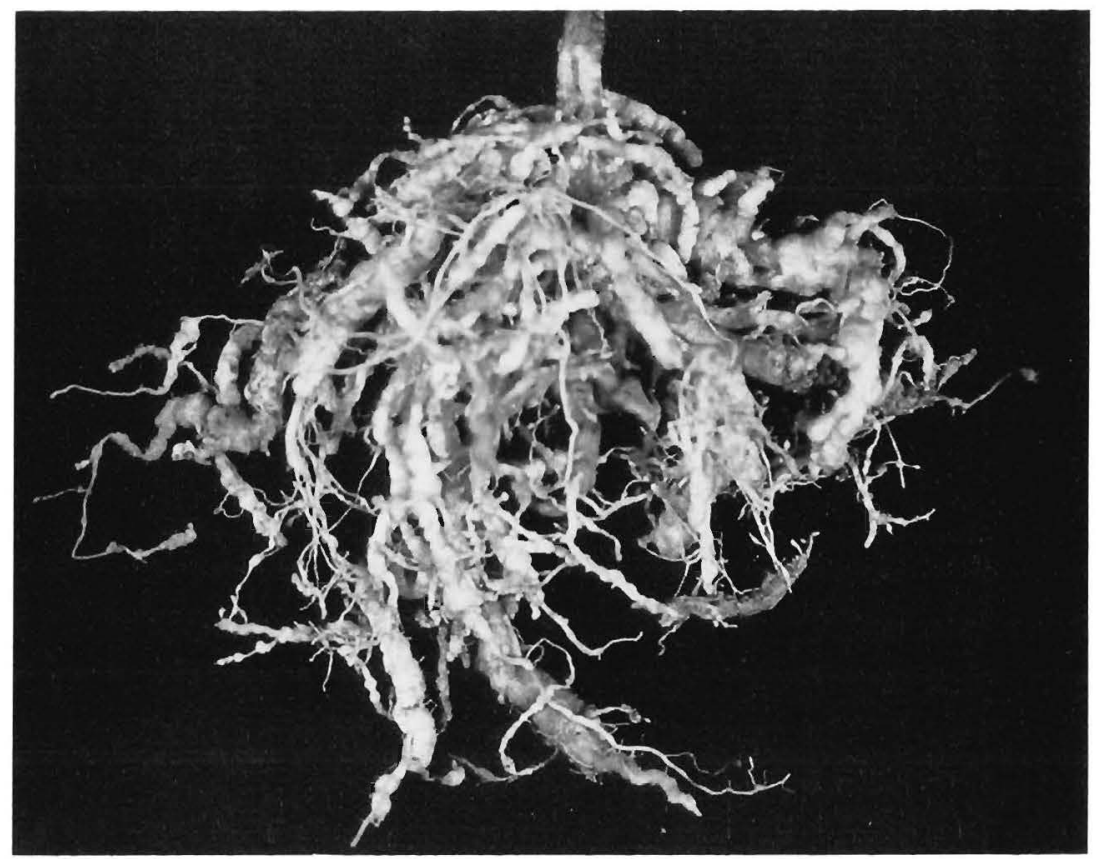

FiG. 3.--Roots of a plant inoculated with the nematode and fungus simultaneously. Roots are highly affected with root galls.

indices were obtained from the roots of plants inoculated with the fungus 4 and 6 days before the nematode (fig. 5) than the other treatments inoculated with the nematode alone or the fungus alone.

The data obtained from these two experiments demonstrated that $P$. lilacinus effectively controlled $M$. incognita. There was more effective control of the nematode by the fungus as we increased the time lapse between the addition of the fungus and the addition of the nematode in the same treatment. This can be explained by the fact that since the 
inoculum used was basically formed by fungus spores, by adding the fungus before the nematodes we were allowing enough time for the spores to germinate, to develop the mycellium and to infect the nematode eggs or larvae.

Similar experiments can be conducted in the field only when it is free of Meloidogyne so that the nematode, as well as the fungus, can be manipulated as desired. On the other hand, when the soil is naturally infested with root knot nematodes, only the fungus can be manipulated,

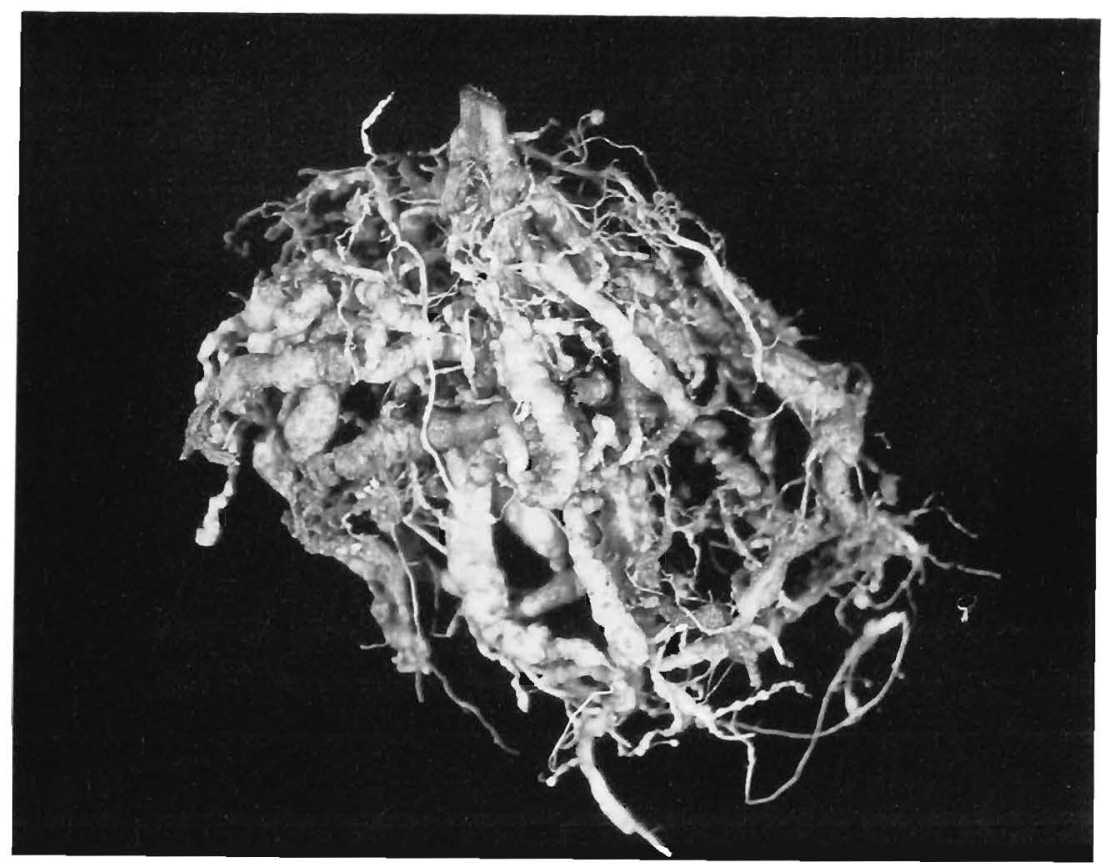

FIG. 4.- Roots of a plant inoculated with the fungus 6 days after the nematode, showing the high number of root galls.

in which case its manipulation has to be planned according to the planting time of the crop. In field experiments conducted in Peru (1) to control root knot nematodes in potatoes, the most effective treatment was the one when the fungus was added at planting time. In this case the inoculum was composed of spores as well as with enough mycellium to parasitize and kill most of the nematode eggs and larvae before they could infect the potatoes. The fungus once established in the field can remain there for several years. Jatala ${ }^{3}$ informed that infestations of the fungus has

\footnotetext{
${ }^{3}$ Personal communication from Dr. Parviz Jatala.
} 


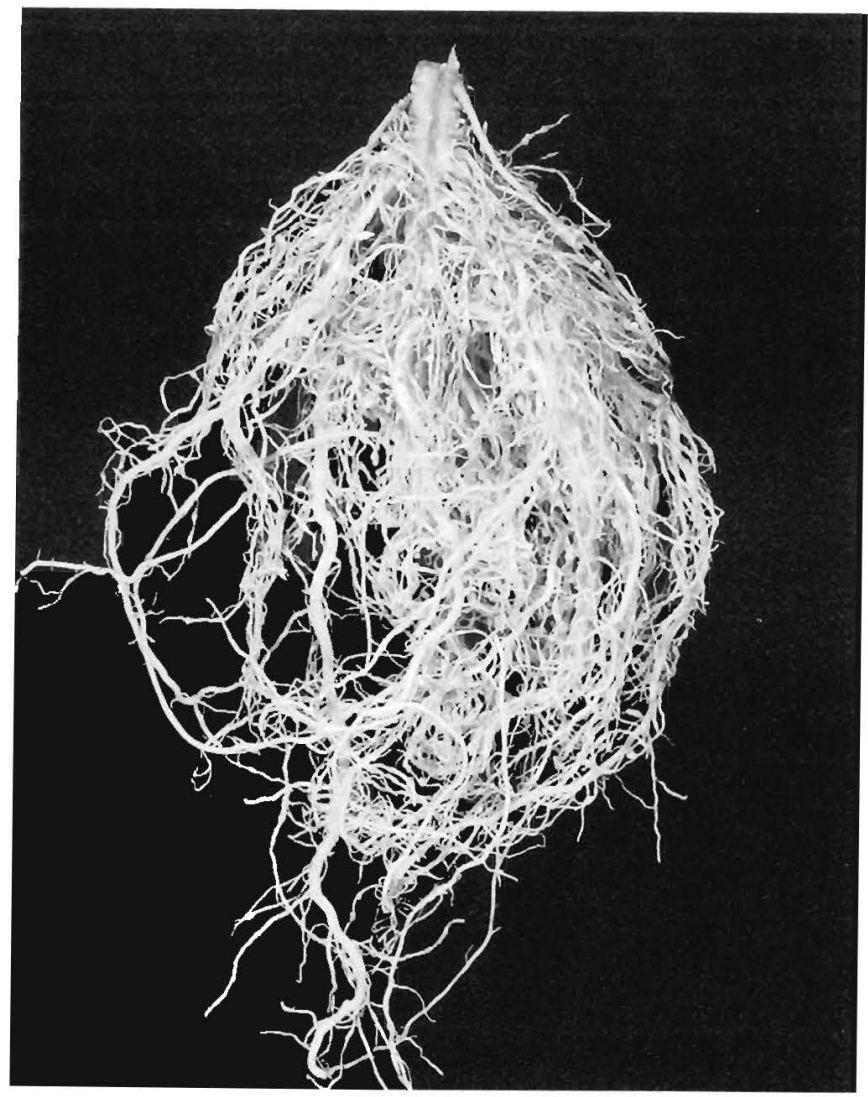

FIG. 5.-Roots of a plant inoculated with the fungus 6 days before the nematode, showing the low incidence of root galls.

remained active in the soil for at least 4 years after the inoculation. This undoubtedly is a great advantage for this method or nematode control because the fungus is not known to be detrimental to other plants or animals.

\section{RESUMEN}

En el invernadero se realizaron dos experimentos para determinar el efecto del hongo Paecilomyces lilacinus sobre la población de larvas de Meloidogyne incognita y la nodulación producida en las raíces de la cultivar de tomate Floradel. Las plantas se inocularon con el hongo solo, el nematodo solo o con ambos a diferentes intervalos de tiempo. A los 60 dias el hongo controló los nematods y redujo la formación de nódulos en las raíces. En el primer experimento, las plantas que se inocularon con el 
hongo 3 días antes de inocularlas con el nematodo y el suelo adyacente tenian significativamente menos nematodos. Estas plantas arrojaron un índice de nodulación más bajo que las plantas que se inocularon con el nematodo solo, con el hongo y el nematodo simultáneamente o con el hongo 3 dias después que con el nematodo.

En el segundo experimento se observó una tendencia a disminuir el número de nematodos en el suelo y en las raices y el indice de nodulación según aumenta el tiempo (en dias) de la inoculación del hongo antes que la del nematodo. Las plantas inoculadas con el hongo 4 y 6 dias antes que con el nematodo arrojaron un índice de nodulación significativamente más bajo que los demás tratamientos.

\section{LITERATURE CITED}

1. Anónimo, 1980. Un hongo como control biológico del nematodo del nudo de la raiz, Circular Centro Internacional de la Papa, Lima, Perú 8 (10): 1-4.

2. Candanedo-Lay, E., Lara, J., Jatala, P. y Gonzảlez, F., 1982. Evaluación preliminar del comportamiento de Paecilomyces lilacinus como controlador biológico del nematodo nodulador, Meloidogyne incognita, en tomate industrial, Nematropica 12: 154.

3. - Rodríguez-Ch., R. y Jatala, P., 1982. Evaluación preliminar del comportamiento de Paecilomyces lilacinus como controlador biológico del nematodo del quiste de la papa, Nematropica 12: 154.

4. Christie, J. R. and Perry, V. G., 1951. Removing nematodes from soil, Proc. Helminthol. Soc. Wash. 18: 106-08.

5. Dunn, M. T., Sayre, R. M., Correll, A. and Wergin, W. R., 1982. Colonization of nematode eggs by Paecilomyces lilacinus (Thom) Samson as observed with scanning electron microscope, Scanning Electron Microscopy 3: 1351-357.

6. Godoy, G., Rodríguez-Kàbana, R. and Morgan-Jones, G., 1982. Parasitism of eggs of Heterodera glycines and Meloidogyne arenaria by fungi isolated from cysts of $H$. glycines, Nematropica 12: 111-19.

7. — - - - and — 1983. Fungal parasites of Meloidogyne arenaria eggs in an Alabama soil. A mycological survey and greenhouse studies, Nematropica 13: 201-13.

8. Jatala, P., Kaltembach, R. and Bocangel, M., 1979. Biological control of Meloidogyne incognita acrita and Globodera pallida on potatoes, J. Nematol. 11: 303.

9. —, - - - Devaux, A. J. and Campos, R., 1980. Field application of Paecilomyces lilacinus for controlling Meloidogyne incognita on potatoes, J. Nematol. 12: 226-27.

10. — Salas, R., Kaltenbach, R., and Bocangel, M., 1981. Multiple application and longterm effect of Paecilomyces lilacinus in controlling Meloidogyne incognita under field condition, J. Nematol. 13: 445.

11. Sterling, G. R. and Mankau, R., 1978. Dactylella oviparasitica, a new fungal parasite of Meloidogyne eggs, Mycologia 70: 774-83.

12. Taylor, A. L. and Sasser, J. N., 1978. Biology, identification and control of root-knot nematodes (Meloidogyne species), North Carolina State Univ. Graphics, 111 p. 